\title{
USAHA PENINGKATAN EKONOMI PADA INDUSTRI RUMAH TANGGA "PARAS PUTRA JAYA" MELALUI BANTUAN PROGRAM KEMITRAAN MASYARAKAT
}

\author{
I Putu Ramayasa ${ }^{1}$, I Gusti Agung Vony Purnama ${ }^{2}$ \\ Institut Teknologi dan Bisnis STIKOM Bali \\ J1. Raya Puputan No.86, Dangin Puri Klod, Kec. Denpasar Tim., Kota Denpasar, Bali \\ Email: ${ }^{1}$ ramayasa@ stikom-bali.ac.id, ${ }^{2}$ vony@ stikom-bali.ac.id
}

\begin{abstract}
Abstrak
Wilayah kecamatan Pupuan kabupaten Tabanan-Bali yang berada di dataran tinggi di kaki gunung Batukaru menjadikannya tempat yang ideal untuk mengembangkan perkebunan kopi. Mitra yang digandeng untuk PKM ini yaitu Industri Rumah Tangga (IRT) "Paras Putra Jaya" yang beralamat di desa Padangan. Produksi kopi Robusta bubuk yang diberi brand "Dua Cangkir" ini telah dijalankan sejak tahun 2002. Beberapa permasalahan utama yang dihadapi oleh mitra saat proses produksi diantaranya penjualan yang menurun karena terlalu banyak adanya pesaing, mesin-mesin yang digunakan masih manual serta kemasan yang masih sederhana. Kemudian pada manajemen pemasaran, diperlukan riset pasar untuk mengetahui segmen pasar dan minat konsumen, serta diperlukan promosi tambahan baik secara offline maupun online. Solusi yang disepakati bersama antara tim PKM dan mitra adalah, pada bagian produksi, menambahkan varian baru yakni kopi rasa coklat yang khas dengan mencampurkan biji kakao kering hasil perkebunan masyarakat sekitar, pengadaan mesin, serta pembuatan kemasan baru dengan tampilan yang menarik dan modern. Sedangkan untuk meningkatkan kualitas manajemen usaha, maka solusinya adalah dengan melakukan riset pasar, memberikan pelatihan dan mendampingi mitra dalam pembuatan iklan pada media online serta memberikan sebuah aplikasi penjualan dan website usaha kepada IRT "Paras Putra Jaya".
\end{abstract}

Kata Kunci : kopi bubuk, Robusta, Pupuan

\begin{abstract}
Pupuan area in the Tabanan regency of Bali is situated in the slope of Mt. Batukaru, which is ideal for coffee plantations. The partner of this program is a home industry namely Paras Putra Jaya located in the village of Padangan, Pupuan which produces powdered coffee beans under the brand name "Dua Cangkir" since 2002. Some of the problems that are faced by Paras Putra Jaya are the decreasing number of products sold because of market competition, traditional production process, the packaging that is outdated and less promoted products. The solutions that are offered including procurement for better production tools, online and offline promotion, new label and packaging, and adding a new variant of coffee product to expand the target market.
\end{abstract}

Keywords: coffee, Robusta, Pupuan

\section{Pendahuluan}

Saat ini, konsumsi kopi dunia mengalami peningkatan yang cukup tajam yaitu ratarata sebanyak $1.7 \%$ per kapita. Tidak ketinggalan konsumsi kopi di Indonesia yang juga mengalami peningkatan sekitar 7 persen setiap tahunnya [1]. Hal ini akan berdampak positif bagi sector perkebunan kopi di tanah air, sebab Indonesia juga adalah produsen kopi peringkat ketiga terbesar di dunia [2]. Ini dikarenakan Indonesia memiliki iklim tropis 
sehingga tanaman kopi dapat berkembang dengan baik hampir di seluruh wilayahnya. Tak ketinggalan provinsi Bali yang juga memiliki perkebunan kopi, baik jenis Robusta, Arabika maupun Luwak.

Wilayah kecamatan Pupuan, yang berada di dataran tinggi di kaki gunung Batukaru menjadikannya tempat yang ideal untuk mengembangkan perkebunan kopi. Hingga saat ini totalnya terdapat sekitar 7700 hektar dari luas wilayahnya yang dimanfaatkan untuk perkebunan kopi [3], dimana jenis yang dikembangkan adalah kopi Robusta. Dapat dikatakan, perekonomian daerah ini sangat bergantung dari sektor perkebunan, khususnya kopi. Desa Padangan adalah salah satu desa di kecamatan Pupuan, yang jaraknya sekitar 75 kilometer dari pusat kota Denpasar, juga adalah sebagai penghasil kopi jenis Robusta. Karena metode penanaman kopi yang diterapkan di daerah ini adalah metode tumpang sari, dimana tanah kosong di sela-sela tanaman kopi dimanfaatkan oleh para petani untuk menanam Kakao [4]. Oleh karena ini pula, citarasa kopi Pupuan menjadi lebih unik, yaitu lebih terkenal dengan citarasa coklat-nya.

Selain pertanian dan perkebunan, di desa Padangan juga terdapat industri yang mengolah biji kopi menjadi produk pangan, berupa kopi bubuk, seperti halnya yang dilakukan oleh mitra yang digandeng untuk PKM ini yaitu Industri Rumah Tangga (IRT) "Paras Putra Jaya" yang dipimpin dan dikelola langsung oleh bapak I Nengah Seraya. Produksi kopi Robusta bubuk yang diberi brand "Dua Cangkir" ini telah dijalankan sejak tahun 2002 dan dalam proses produksinya, bapak Nengah dibantu oleh 3 orang tenaga kerja yang berasal dari wilayah sekitar desa. Untuk produknya, IRT ini telah mengantongi sertifikat penyuluhan yang diawasi oleh Dinas Kesehatan RI dengan nomor: SP. 443/457/2002. Pasokan bahan baku utama, yaitu biji kopi Robusta kering, didapatkan dari petani sekitar dengan jumlah 1 hingga 3 kwintal per bulannya. Kemudian kopi dijual per bungkus dengan ukuran 50, 100, 200 gram, dengan kemasan berupa plastik lengkap dengan brand/merk dagangnya yang dijual dengan harga masing-masing sebesar Rp. 2.500, Rp. 5.000 dan Rp. 10.000. Sedangkan untuk permintaan dalam ukuran yang lebih besar, dilayani dengan kemasan sederhana berupa plastik kiloan. Dimana, 1 kilogram kopi bubuk saat ini dijual dengan harga Rp. 50.000. Dengan demikian, penghasilan yang didapatkan adalah sekitar 5 sampai dengan 15 juta rupiah per bulannya, tergantung dari banyaknya jumlah permintaan.

Proses produksi kopi Robusta bubuk pada industri rumah tangga (IRT) "Paras Putra Jaya", seperti yang diilustrasikan pada Gambar 1.1, dimulai dari tahap pemilihan biji kopi kering yang kondisinya baik dan layak konsumsi. Biji kopi terpilih kemudian dicuci menggunakan air. Setelah bersih, dilanjutkan dengan proses penjemuran sekali lagi di bawah terik matahari sampai biji kopi benar-benar kering. Penjemuran dilakukan dengan mengatur dan menebar kopi di atas para-para atau drying bed. Proses dilanjutkan dengan menyangrai biji kopi yang telah kering menggunakan alat sangrai sederhana berbentuk drum/silinder yang dipanaskan menggunakan dua buah kompor jenis satu tungku high pressure. Alat sangrai ini diputar secara manual dengan tangan, yang bertujuan agar biji kopi yang ada di dalamnya mendapatkan panas secara merata. Karena alat sangrai ini tertutup, sangrai akan dihentikan apabila telah tercium aroma tertentu yang menandakan kopi telah matang sesuai dengan standar IRT "Paras Putra Jaya ". Kopi yang telah disangrai kemudian didinginkan dan setelah dingin dilanjutkan dengan proses penggilingan. Dalam hal ini, mesin penggilingan yang digunakan oleh mitra berupa penggilingan tepung yang kapasitasnya kurang lebih 2 kilogram. Hasil biji kopi yang digiling adalah berupa kopi bubuk yang siap untuk dikemas. Pengemasan dilakukan dengan menggunakan plastik kemasan yang telah disablon. Sedang untuk merekatkan kemasan, IRT ini memanfaatkan mesin pres listrik berukuran sedang. Waktu yang diperlukan dari tahap pensortiran sampai produk dikemas 
adalah rata-rata dua hari. Keseluruhan proses produksi ini dapat dilihat melalui foto-foto yang disajikan pada Gambar 1.

Ide untuk menjalankan usaha ini didapatkan dari pemikiran bapak I Nengah Seraya sendiri bahwa kopi bubuk, utamanya di Bali, sudah seperti kebutuhan primer dimana setiap orang memerlukannya. Ditambah lagi di Bali terdapat berbagai macam upacara adat/agama yang juga memerlukan penggunaan kopi bubuk. Ide ini, kemudian direalisasikan dengan memproduksi kopi bubuk dengan cara sederhana dan berdasarkan pengalaman saja. Sampai saat ini proses produksi belum pernah dikembangkan, diperbaiki ataupun dianalisa ulang walaupun terdapat kecenderungan bahwa penjualan kopi bubuk produknya saat ini mengalami penurunan. Hanya satu alasan yang diberikan oleh bapak I Nengah Seraya, yakni terlalu banyaknya saingan. Melihat kecenderungan ini dan potensi daerah Padangan maupun Pupuan secara keseluruhan yang tidak hanya terkenal dengan hasil biji kopinya, namun juga terkenal sebagai daerah penghasil biji kakao, maka muncul keinginan mitra untuk membuat varian kopi baru dengan citarasa khas Pupuan yaitu rasa cokelat. Para tetua di wilayah ini, sejak jaman dahulu sering menyangrai kopi yang dicampur dengan biji kakao kering dan hasil kopinya salah satu jenis yang digemari. Terdapat kemungkinan bila varian ini diproduksi, maka hasil penjualan pada IRT "Paras Putra Jaya" akan meningkat karena segmen pasar yang akan semakin besar.

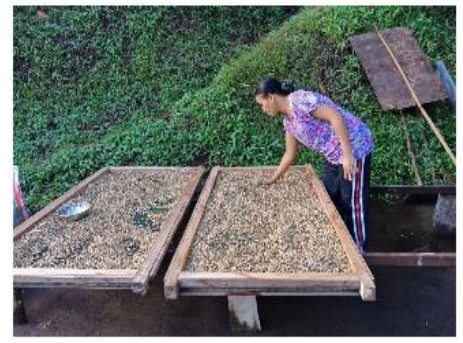

(a)

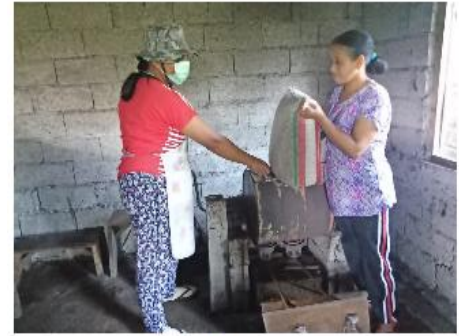

(b)

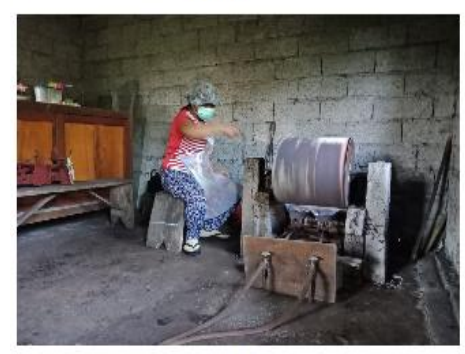

(c)

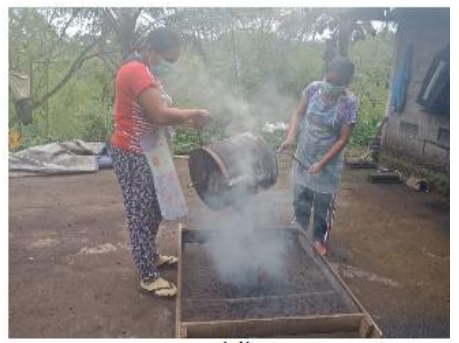

(d)

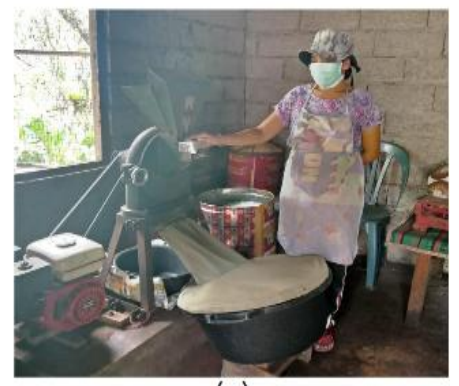

(e)

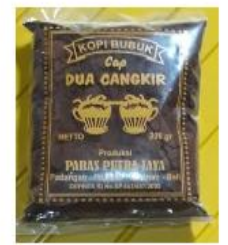

(f)

Gambar 1. Proses produksi kopi Robusta bubuk pada IRT "Paras Putra Jaya", dimana biji kopi pilihan yang telah dicuci sebelumnya akan mengalami (a) proses pengeringan, kemudian (b) mempersiapkan proses sangrai, (c) proses sangrai kopi yang diputar secara manual, (d) mendinginkan biji kopi yang disangrai, selanjutnya proses (e) penepungan dan terakhir kopi bubuk dari hasil penepungan (f) dikemas menggunakan plastik kemasan. 
Dari hasil wawancara pula, didapatkan penjelasan mengenai manajemen usaha pada IRT "Paras Putra Jaya" sebagai berikut. Pembelian biji kopi dilakukan secara mandiri, dimana pihak IRT "Paras Putra Jaya" akan mendatangi penjual/suplier secara langsung dan semua transaksi dilakukan tanpa melakukan pencatatan. Menurut bapak I Nengah Seraya, Ini dilakukan karena jumlah kopi yang dibeli relatif sedikit dan pembelian hanya dilakukan sebulan sekali. Sedangkan pencatatan hasil penjualan produk, selama ini dilakukan dengan cara manual dalam sebuah buku catatan. Dalam hal penyimpanan, biji kopi yang dibeli disimpan dengan cara sederhana yakni menggunakan karung goni. Ini dianggap cukup baik karena biasanya proses produksi langsung dilakukan secara bertahap setelah pembelian biji kopi, sehingga penyimpanan sifatnya hanya sementara saja. Karung goni juga memilik poripori yang dapat membantu perputaran udara sehingga kopi tidak mudah lembab dan berjamur. Kemudian, setiap kali selesai masa produksi biasanya produk yang dihasilkan akan habis dipasarkan dalam waktu satu atau maksimal dua minggu sehingga produk yang dihasilkan terjamin kesegarannya.

Dari segi pemasaran, sejak dimulainya produksi kopi di IRT "Paras Putra Jaya", metode pemasaran hanya dilakukan dengan 2 cara yakni, yang pertama, dengan menjual produk ke toko/swalayan/pasar di sekitaran wilayah Pupuan dengan mengunjungi langsung tempat-tempat tersebut dan metode kedua adalah dengan menjualnya kepada distributor maupun perorangan yang datang ke tempat produksi. Bapak I Nengah Seraya menjelaskan jika saja pemasaran produknya dapat menjangkau daerah atau wilayah yang lebih luas, maka penjualan niscaya akan meningkat. Namun keinginan ini terbentur upah yang belum mampu diberikan apabila merekrut tenaga kerja tambahan. Saat ini, pengelolaan usaha dan pemasaran hanya dilakukan oleh bapak I Nengah Seraya sendiri.

Tujuan utama dari kegiatan PKM ini adalah untuk membantu IRT "Paras Putra Jaya" untuk menyelesaikan permasalahan yang dihadapi saat ini dan meningkatkan pengelolaan usaha pada lingkungan internal-nya, sehingga diharapkan nanti daya saing dan hasil penjualan pada IRT ini mampu mengalami pengingkatan, karena peningkatan pada hasil penjualan akan berdampak langsung ke usaha, pegusaha dan tenaga kerjanya. Dampak ini juga akan berpengaruh secara tidak langsung ke peningkatan perekonomian dan kesejahteraan masyarakat desa Padangan. Usaha peningkatan hasil penjualan ini akan dilakukan dari dua bagian yang urgent, yakni bagian produksi dan bagian manajemen usaha, utamanya manajemen pemasaran.

\section{Masalah}

Berdasarkan informasi analisis situasi, permasalahan mitra dapat diidentifikasikan menjadi beberapa pokok permasalahan, yaitu:

Berdasarkan sub bab Analisis Masalah di atas dan berdasarkan kesepakatan bersama mitra, maka permasalahan prioritas mitra adalah sebagai berikut.

a) Permasalahan bagian produksi

- Diperlukan satu set peralatan sangrai baru dengan kapasitas lebih besar agar proses produksi dapat diselesaikan dalam waktu yang lebih singkat. Set peralatan yang diharapkan akan lebih baik dibandingkan yang dimiliki mitra saat ini, termasuk difasilitasi dengan termometer pengontrol suhu.

- Diperlukan sebuah mesin penepung baru yang lebih baik dan dengan kapasitas yang lebih besar agar proses produksi, utamanya penggilingan kopi, menjadi lebih efisien dan efektif.

- Diperlukan sebuah inovasi baru dengan cara membuat varian kopi bubuk baru, yaitu misalnya dengan memunculkan ciri khas kopi Pupuan dengan rasa coklatnya yang lebih kuat. Ini dapat dilakukan dengan memanfaatkan biji kakao kering yang juga dihasilkan oleh petani sekitar desa Padangan dan kecamatan Pupuan. Dan untuk membuat campuran 
yang layak untuk diperjual-belikan, diperlukan pelatihan intensif dalam meracik produk kopi yang diinginkan. Ini juga akan menambah wawasan dan pengetahuan mitra sehingga produk yang dihasilkan nantinya sesuai dengan standar.

- Sertifikat Penyuluhan dari dinas kesehatan juga perlu diperbaharui dengan sertifikat PIRT untuk meyakinkan konsumen bahwa produk-produk yang dihasilkan oleh IRT "Paras Putra Jaya" aman dan terjamin kualitasnya dalam hal kesehatan. Karena untuk mendapatkan sertifikat P-IRT, produk yang dihasilkan oleh mitra harus melalui proses uji laboratorium terlebih dahulu.

- Diperlukan desain kemasan baru dan modern sehingga tampilan produk dapat lebih profesional dan menarik untuk pemasaran dengan jangkauan pasar yang lebih luas.

b) Permasalahan bagian manajemen usaha

- Perlu dibuatkan sebuah aplikasi pencatatan transaksi jual beli berbasis mobile phone dan cloud computing yang nantinya dapat diakses dan dikelola oleh pihak pengelola IRT, yakni bapak I Nengah Seraya.

- Perlu dilakukan survei/riset pasar sehingga IRT "Paras Putra Jaya" memiliki segmen pasar yang lebih spesifik. Dengan survei ini pula, produk yang dihasilkan dapat disesuaikan dengan kebutuhan segmen pasar tersebut.

- Diperlukan pembuatan iklan pada media massa dan media sosial untuk memasarkan produknya.

- Diperlukan pelatihan pemanfaatan media sosial untuk pemasaran produk, sehingga produknya dapat menjangkau wilayah yang lebih luas.

- Diperlukan sebuah website yang memberikan informasi tentang produk kopi cap "Dua Cangkir". Ketersediaan website ini sangat penting di era e-commerce jaman sekarang.

\section{Metode Pelaksanaan Pengabdian}

Berdasarkan permasalahan yang telah diidentifikasi pada bagian Pendahuluan dan solusi yang ditawarkan pada bagian Solusi Permasalahan, maka langkah yang akan dilakukan dalam melaksanakan solusi dari permasalahan mitra adalah berupa metode pendekatan yang dibagi ke dalam dua jenis, yaitu metode pendekatan untuk permasalahan produksi dan metode pendekatan untuk permasalahan manajemen pemasaran.

\subsection{Permasalahan Produksi}

Metode pendekatan pada kategori ini dibagi menjadi tiga tahap yaitu pengadaan\&sosialisasi, pelatihan, dan pendampingan.

a. Pengadaan dan Sosialisasi

Pengadaan dilakukan dengan memberikan alat bantuan berupa mesin sangrai kopi dengan kapasitas yang lebih besar dan modern, serta mesin penepung yang juga lebih baik dari yang dimiliki mitra saat ini. Selain berupa barang, juga akan diberikan pengadaan tenaga ahli untuk memberikan pelatihan pembuatan kopi sehingga rencana penambahan varian kopi pada kegiatan PKM ini dapat terealisasi dengan baik.

Sosialisasi yang diberikan kepada mitra, baik dalam kaitannya dengan dilaksanakannya kegiatan PKM ini maupun berupa penjelasan mengenai perlunya penambahan peralatan berupa mesin serta informasi perlunya mengganti sertifikat penyuluhan menjadi sertifikat Pangan Industri Rumah Tangga (P-IRT), dilakukan secara bertahap bersama tim. Sosialisasi ini diperlukan untuk menghindari kesalahpahaman dengan mitra.

b. Pelatihan

Pelatihan yang akan dilaksanakan adalah seperti misalnya pelatihan pemanfaatan media sosial dan pelatihan produksi kopi dalam rangka membuat varian kopi yang baru . Pelatihan-pelatihan ini rencananya akan dilaksanakan secara klasikal dalam suasana "kelas 
belajar". Dengan suasana kelas belajar seperti ini diharapkan materi yang sifatnya teori dapat dipahami dengan lebih baik. Kemudian selain berupa "kelas belajar", akan diberikan juga pelatihan secara praktikal menggunakan alat yang telah diadakan sebelumnya.

c. Pendampingan

Pendampingan dilakukan selama proses produksi dilakukan oleh mitra untuk memastikan bahwa barang dan pelatihan yang diberikan dapat dijalankan secara mandiri serta menggunakan peralatan maupun barang sesuai petunjuk pemakaian.

\subsection{Permasalahan Manajemen Usaha}

Permasalahan dalam bidang manajemen usaha, khususnya bidang pemasaran, yang dialami mitra akan diselesaikan sesuai solusi yang telah dijabarkan sebelumnya, yaitu dengan cara memberikan sosialisasi dan pelatihan dengan memanfaatkan media online, baik berupa website maupun iklan di media sosial. Kegiatan ini bertujuan untuk memperluas segmen pasar sehingga diharapkan nantinya dapat meningkatkan hasil penjualan produk dari mitra. Metode pendekatan yang dilakukan dalam melaksanakan solusi permasalahan pada bidang ini dibagi menjadi tiga kategori, yakni sosialisasi dan pelatihan, pendampingan dan survey.

a. Sosialisasi dan Pelatihan.

Kegiatan sosialisasi bertujuan untuk memberikan informasi mengenai solusi untuk kegiatan pemasaran, misalkan mengenai penyediaan software jual-beli, pemasangan iklan di media sosial dan penyediaan website. Setelah terjadi kesepahaman, maka selanjutnya dilakukan kegiatan pelatihan. Dalam hal ini misalnya pelatihan pemanfaatan media sosial, sehingga nantinya mitra dapat dilepas secara mandiri.

b. Pendampingan.

Pendampingan bertujuan untuk memastikan bahwa kedua mitra mampu menerapkan hasil pelatihan yang telah diberikan secara mandiri.

c. Survey

Untuk kegiatan survey pasar, maka setelah sosialisasi dilaksanakan, tim akan menyediakan seorang tenaga petugas survey untuk membantu melakukan survey pasar yang kemudian informasi yang didapat akan diolah dan dianalisa. Hasilnya akan diberikan kepada tim PKM dan mitra untuk ditindak lanjuti.

\section{Pembahasan}

\subsection{Pembahasan Kegiatan}

Kegiatan pengabdian kepada maasyarakat dengan mitra produsen kopi bubuk Bapak Nengah Seraya yang beralamat di Desa Padangan, Kec. Pupuan - Tabanan ini dimulai dengan kegiatan survey lapangan yang dilakukan oleh tim pengabdian pada Juni 2018. Kemudian, setelah terjalin kesepakatan kerja sama dengan mitra maka kegiatan pengabdian kepada masyarakat ini, dengan sepengetahuan Kepala Desa/Perbekel dan Kelian setempat, dilanjutkan ke tahap berikutnya.

Setelah tahap pengajuan proposal selesai dan kemudian diikuti dengan disetujuinya kegiatan ini untuk didanai berdasarkan surat kontrak pengabdian No 186/P2M/STIKOM/WDS/IV/19 tertanggal 8 April 2019 dan juga berdasarkan surat Tugas Nomor: 283/P2M/STIKOM/WDS/V/2019 tanggal 9 Mei 2019, maka tim pelaksana kegiatan PKM ini memulai kegiatan sesuai yang telah direncanakan sebelumnya. Hingga saat ditulisnya laporan kemajuan ini, terdapat beberapa poin penting atau kegiatan utama yang telah dilakukan, yaitu: sosialisasi kegiatan kepada mitra, serah terima barang, pembuatan iklan pada media sosial, workshop kopi pasca panen, pelatihan pemanfaatan media social, pendampingan serta publikasi media massa. Berikut adalah penjelasannya secara detail. 


\subsection{Sosialisasi Kegiatan Kepada Mitra}

Sosialisasi kegiatan dilakukan dalam dua tahap, yaitu pada tahap pertama untuk menjajagi kesepakatan kerja sama. Dan tahap kedua adalah ketika proposal telah disetujui akan didanai oleh DRPM-Kemenristekdikti. Pada kegiatan ini dilakukan pula audiensi kebutuhan mitra. Segala keperluan mitra yang sekiranya dapat dibantu kemudian di-list oleh tim untuk kemudian dilakukan pengadaan baik berupa barang maupun jasa. Gambar 2 menunjukkan kegiatan sosialisasi pada kedua mitra.

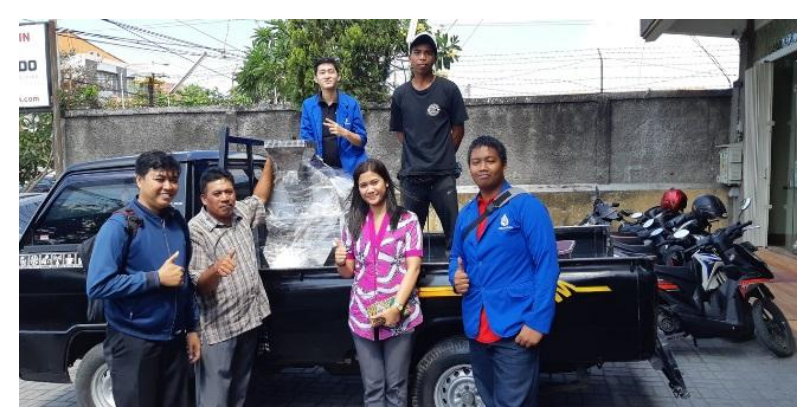

Gambar 2. Sosialisasi kegiatan PKM pada mitra pengabdian

\subsection{Serah Terima Barang}

Dikarenakan terdapat beberapa barang yang harus diawali dengan pemesanan terlebih dahulu, maka serah terima barang kemudian dilakukan dalam 2 tahap. Tahap pertama adalah serah terima mesin roasting. Tahap kedua, yang seharusnya mesin penepung sesuai kesepakatan di awal kemudian dialihkan menjadi mesin vertical sealer. Alasan pengalihan ini adalah karena ternyata mesin penepung yang menggunakan tenaga listrik memerlukan daya yang sangat tinggi yaitu 1500 Watt dimana mitra PKM saat ini belum memiliki daya sebesar itu dan apabila dihitung jumlah pengeluaran untuk membayar listrik jatuhnya lebih tinggi daripada membeli bensin. Dengan alasan inilah maka mesin penepung kemudian dialihkan ke mesin lain, yakni vertical sealer, yang juga tak kalah pentingnya untuk membuat tampilan produk menjadi lebih baik dan modern. Pemilihan barang dilakukan secara berhati-hati, terutama dari segi kualitas. Ini dikarenakan barang-barang tersebut akan digunakan setiap hari untuk membantu proses produksi kopi pada mitra PKM. Ketika memilih barang, tim selalu berusaha memilih barang dengan material yang baik, misalnya memilih bahan aluminium dan bukan besi.

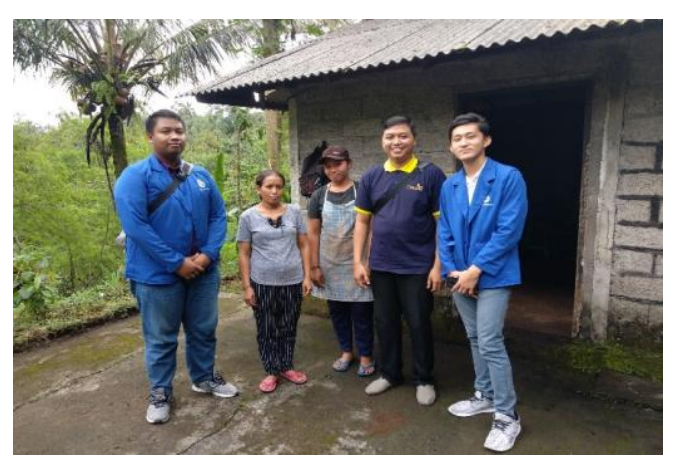

Gambar 3. Serah terima barang berupa mesin roasting/sangrai kepada mitra pengabdian. 


\subsection{Pembuatan Iklan pada Media Sosial}

Sesuai dengan kesepakatan bersama, maka dibuatlah page atau akun pada beberapa media sosial populer, yaitu Instagram dan Facebook. Dari promosi ini terdapat respon positif dari pengguna lain, sehingga menambah semangat kerja mitra untuk lebih meningkatkan produk mereka. Selain media sosial, produk mitra juga telah mulai diperdagangkan pada marketplace yakni Tokopedia. Diharapkan dengan penjualan produk semacam ini akan meningkatkan jumlah produksi dan penjualan kopi pada mitra PKM.

\subsection{Pembuatan Label Kemasan}

Dari kemasan yang masih berupa plastik tanpa label, tim PKM kemudian memberikan rancangan label kemasan untuk mitra. Label kemasan ini juga adalah salah satu syarat dalam pengurusan ijin Produk Pangan Industri Rumah Tangga (P-IRT). Gambar label baru yang didesainkan oleh tim pengabdian adalah seperti terlihat pada Gambar 4.

Saat proses pengurusan dokumen PIRT, dari hasil penelusuran secara online tim pengabdian mendapati bahwa nama merk "Cap Dua Cangkir" ternyata telah digunakan oleh beberapa produsen, salah satunya berasal dari luar pulau. Untuk menghindari kejadian yang tidak diinginkan yang disebabkan oleh kesamaan merk ini, maka tim pengabdian memberikan solusi untuk menggunakan nama baru yang unik dan belum digunakan oleh produsen lain. Hasil diskusi bersama mitra, akhirnya disepakati nama merk "Cap Dua Cangkir" diubah ke "Cap Cangkir Mulia" seperti yang tertulis pada rancangan label Gambar 4. Dengan adanya temuan dan perubahan nama merk, mitra merasakan manfaat yang lebih besar berkat adanya bantuan hibah yang diterima.

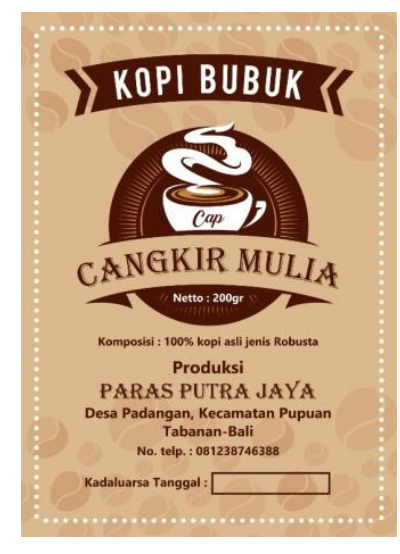

Gambar 4. Label baru produk kopi bubuk mitra PKM.

\subsection{Pengurusan P-IRT}

Sejak tanggal 3 Juli 2019, pengurusan ijin P-IRT mitra mulai dilaksanakan oleh tim PKM. Segala kepentingan pengurusan dokumen dibantu dan didampingi oleh tim. Kemudian dokumen persyaratan diserahkan ke dinas perijinan kab. Tabanan dan kemudian pada tanggal 3 September 2019, tim dari dinas Perijinan kab. Tabanan beserta tim lab melakukan visitasi dan pengecekan terhadap produk dan proses produksi kopi bubuk pada mitra PKM dalam rangka penerbitan ijin edar PIRT. Dan akhirnya pada tanggal 17 September 2019, ijin edar produk mitra telah resmi dikeluarkan dengan no PIRT: 2.10.5102.01.0080.24.

\subsection{Pelatihan Pemanfaatan Media Sosial}

Untuk kegiatan pelatihan pemanfaatan media sosial dilaksanakan di tempat usaha mitra PKM dengan cara dan situasi yang nyaman sehingga materi dapat diserap dengan lebih 
baik. Metode penyampaian yang juga sederhana dan to the point diharapkan dapat memberikan hasil yang maksimal. Kegiatan seperti ini sangatlah menarik, karena menggunakan bahasa sehari-hari dan terbukti dari antusiasme mitra pada saat pelatihan.

\subsection{Pendampingan}

Untuk setiap pengadaan peralatan, tim melakukan pendampingan hingga alat baru yang diberikan dapat dimanfaatkan oleh kedua mitra secara maksimal. Pendampingan tidak hanya dilakukan oleh tim, namun juga dibantu oleh pihak lain seperti pihak teknisi dari toko tempat mesin-mesin bantuan dibeli. Tujuannya adalah demi pendampingan yang juga maksimal disamping ke depannya, mitra tidak akan sungkan berkonsultasi langsung dengan para teknisi di masa depan apabila terdapat gangguan atau masalah pada mesin-mesin tersebut. Dari hasil pendampingan ini, mitra terlihat lebih antusias setelah mendapatkan hasil yang produksi lebih baik dan proses produksi yang lebih cepat dengan kapasitas yang lebih besar.
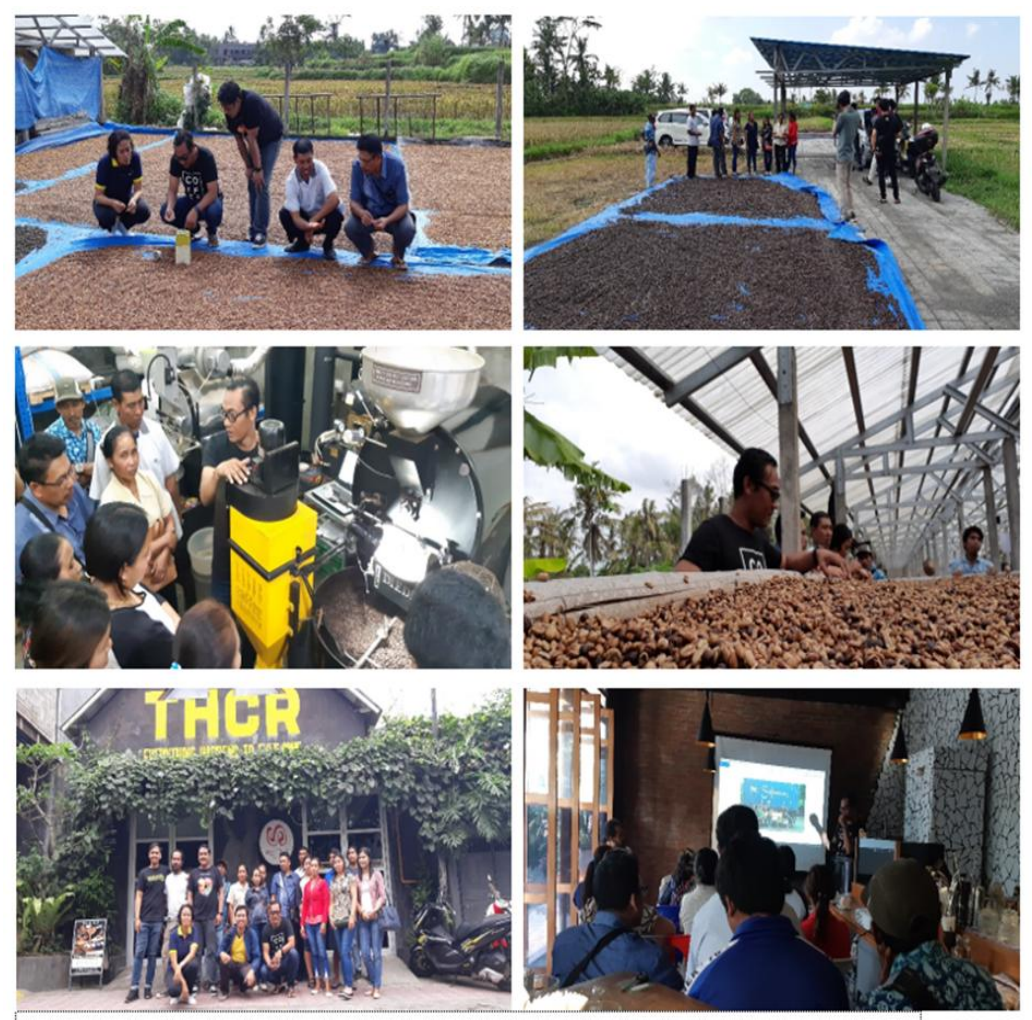

Gambar 5. Workshop pasca panen kopi bekerja sama dengan PT Karana Spesialis Kopi, Gianyar-Bali.

\subsection{Workshop Pasca Panen Kopi}

Untuk meningkatkan wawasan mitra yang akan berdampak terhadap hasil produksi dan kualitas produk, maka pada tanggal 22 Juni 2019, tim pengabdian bersama dengan PT Karana Spesialis Kopi, yang merupakan anak perusahaan dari Seniman Coffee Studio-Ubud, menyelenggarakan workshop pasca panen kopi di Gianyar. Selain mitra, pihak PT Karana juga meminta untuk menyertakan 9 petani kopi lainnya dari desa yang sama untuk disertakan sebagai peserta workshop. Maka, pada hari pelaksanaan, terdapat total 10 petani serta produsen kopi yang ikut serta dalam kegiatan workshop tersebut. Selama berlangsungnya kegiatan, para peserta terlihat antusias dengan materi yang disampaikan, apalagi mereka juga diajak berkeliling melihat tempat pasca panen kopi di PT Karana. Dengan mesin-mesin 
canggih yang digunakan, workshop tersebut telah membuka lebih lebar wawasan dan pengetahuan para peserta. Gambar 5 memperlihatkan kegiatan workshop pasca panen kopi.

\subsection{Publikasi Media Massa}

Untuk memenuhi salah satu target luaran, maka publikasi media massa dilakukan di media Tribun Bali yang akan diterbitkan pada tanggal 16 Agustus 2019 yang dapat diakses pada alamat link https://bali.tribunnews.com/2019/08/16/dosen-itb-stikom-bali-bantuprodusen-kopi-di-desa-padangan-tabanan.

\subsection{Evaluasi Kegiatan}

Setelah 10 kegiatan pokok yang telah dijelaskan maka luaran dan hasil yang telah dicapai dapat dilihat pada tabel 1.

Tabel 1. Hasil dari pemberian solusi permasalahan mitra.

\begin{tabular}{|c|c|c|c|}
\hline No. & Permasalahan & $\begin{array}{l}\text { Solusi } \\
\end{array}$ & Jenis Luaran \\
\hline \multicolumn{4}{|c|}{ Bagian Produksi } \\
\hline 1 & $\begin{array}{l}\text { Diperlukan satu set peralatan sangrai } \\
\text { yang lebih modern dengan termometer }\end{array}$ & $\begin{array}{l}\text { diberikan mesin } \\
\text { sangrai kopi, dengan } \\
\text { spesifikasi Tipe Mesin } \\
\text { : SGR-15 Agrowindo, } \\
\text { Kapasitas: } 15 \mathrm{~kg} \\
\text { proses, Dimensi:133 x } \\
63 \mathrm{x} 110 \mathrm{~cm}, \text { Bahan } \\
\text { Bakar: LPG, Listrik: } \\
450 \text { watt, 220 V, } \\
\text { Bahan: Full Stainless } \\
\text { Steel, Fasilitas: Gratis } \\
\text { kompor LPG }\end{array}$ & $\begin{array}{lrr}\text { Proses } & \text { sangrai yang } \\
100 \% \text { lebih } & \text { efisien, } \\
\text { dimana } & \text { tidak } \\
\text { diperlukan lagi tenaga } \\
\text { kerja dalam memutar } \\
\text { drum sangrai serta } \\
\text { dengan bahan bakar } \\
\text { yang tidak lagi } \\
\text { menggunakan kayu } \\
\text { bakar. } \\
\text { termometer Fasilitas } \\
\text { mengatur suhu juga } \\
\text { akan menambah } \\
\text { efisien kinerja tenaga } \\
\text { kerja. }\end{array}$ \\
\hline 2 & $\begin{array}{l}\text { Diperlukan sebuah mesin penepung } \\
\text { baru yang lebih baik dan dengan } \\
\text { kapasitas yang lebih besar. }\end{array}$ & $\begin{array}{l}\text { Diberikan mesin } \\
\text { penepung dengan type } \\
\text { mesin : AGR-GRP180 } \\
\text { dan kapasitas : } 80-150 \\
\mathrm{~kg} / \mathrm{jam}\end{array}$ & $\begin{array}{l}\text { Dialihkan ke mesin } \\
\text { sealer, karena mesin } \\
\text { penepung yang baru } \\
\text { boros listrik. }\end{array}$ \\
\hline 3 & $\begin{array}{l}\text { Diperlukan sebuah mesin sealer } \\
\text { modern untuk menutup kemasan } \\
\text { berbahan plastik maupun aluminium } \\
\text { foil. }\end{array}$ & $\begin{array}{l}\text { Diberikan } 1 \text { unit } \\
\text { mesin vertical band } \\
\text { sealer MSP-MSL- } 88\end{array}$ & $\begin{array}{l}\text { Mesin sealer dapat } \\
\text { meningkatkan proses } \\
\text { pengemasan dengan } \\
\text { aluminium foil sebesar } \\
100 \% \text { dan sekurangnya } \\
50 \% \text { untuk kemasan } \\
\text { plastik. }\end{array}$ \\
\hline 4 & $\begin{array}{l}\text { Diperlukan desain kemasan baru dan } \\
\text { modern }\end{array}$ & $\begin{array}{l}\text { Dibuatkan kemasan } \\
\text { dengan desain yang } \\
\text { baru dan lebih modern }\end{array}$ & $\begin{array}{l}\text { Desain kemasan } \\
\text { dengan nama merk } \\
\text { yang baru yaitu : Cap } \\
\text { Cangkir Mulia. }\end{array}$ \\
\hline \multicolumn{4}{|c|}{\begin{tabular}{|c|} 
Bagian Manajemen Usaha \\
\end{tabular}} \\
\hline 1 & $\begin{array}{l}\text { Diperlukan pembuatan iklan pada } \\
\text { media massa dan media sosial }\end{array}$ & $\begin{array}{lr}\text { Dibantu membuatkan } \\
\text { iklan pada media } \\
\text { massa dan media }\end{array}$ & $\begin{array}{l}\text { Iklan pada instagram } \\
\text { dan facebook. Menjual } \\
\text { produk online pada }\end{array}$ \\
\hline
\end{tabular}


Usaha Peningkatan Ekonomi Pada Industri Rumah Tangga "Paras Putra Jaya" Melalui Bantuan...

\begin{tabular}{l|l|l|l}
\hline \hline 2 & $\begin{array}{l}\text { Diperlukan pelatihan pemanfaatan } \\
\text { media sosial untuk pemasaran produk }\end{array}$ & $\begin{array}{l}\text { sosial memfasilitasi mitra } \\
\text { dengan pelatihan } \\
\text { pemanfaatan media } \\
\text { sosial }\end{array}$ & $\begin{array}{l}\text { Tokopedia. } \\
\text { Sertifikat pelatihan }\end{array}$ \\
\hline
\end{tabular}

\section{Kesimpulan}

Berdasarkan list kegiatan yang telah dilakukan dan hasil yang telah dicapai, maka dapat disimpulkan bahwa:

1. Dengan sentuhan ipteks, kualitas produksi dan kemasan produk dari mitra mengalami peningkatan yang signifikan,

2. Bantuan yang diberikan kepada mitra telah mampu meningkatkan proses dan hasil produksi kedua mitra,

3. Dengan diadakannya kegiatan seperti ini maka pegiat industri rumahan akan lebih termotivasi untuk majudan meningkatkan kualitas dan kuantitas produk mereka.

\section{Ucapan Terima Kasih}

Ucapan terima kasih penulis ucapkan kepada DRPM Kemenristekdikti yang telah memberi kesempatan dan bantuan untuk pelaksanaan Program Kemitraan Masyarakat ini, Ketua ITB STIKOM Bali atas perhatian dan bantuannya sehingga kegiatan ini berjalan dengan baik, Lembaga P2M ITB STIKOM Bali yang telah banyak membantu terlaksananya Program Kemitraan Masyarakat ini, Ketua program studi Sistem Informasi yang telah memberi kesempatan dan banyak bantuan untuk memperlancar pelaksanaan Program Kemitraan Masyarakat ini, serta semua pihak yang tidak dapat tim kegiatan sebutkan satu per satu yang juga telah banyak membantu terselenggaranya kegiatan ini.

\section{Daftar Pustaka}

[1] Tribunnews, "Konsumsi Kopi Indonesia Naik 7 Persen Setahun", http://www.tribunnews.com/regional/2018/03/22/konsumsi-kopi-indonesia-naik-7persen-setahun, terakhir di akses pada tanggal 23 Agustus 2018, pukul 05:44 WITA

[2] Wikipedia, "Produksi Kopi di Indonesia", https://id.wikipedia.org/wiki/Produksi_kopi_di_Indonesia, terakhir di akses pada tanggal 23 Agustus 2018, pukul 05:48 WITA.

[3] Balipost, "7700 Hektar Tanaman Kopi di Pupuan Perlu Peremajaan”, http://www.balipost.com/news/2018/02/19/38029/7700-Hektar-Tanaman-Kopidi...html, terakhir di akses pada tanggal 23 Agustus 2018, pukul 06:00 WITA.

[4] Budhi, Sri, Made Kembar, and Ni Putu Evi Windasari. "Analisis Pengaruh Tumpangsari terhadap Pendapatan Petani di Desa Munduktemu Kabupaten Tabanan." E-Jurnal Ekonomi Pembangunan Universitas Udayana 2.5 (2013). 
I Putu Ramayasa, I Gusti Agung Vony Purnama 